\title{
ASSESSMENT OF ANTIOXIDANT AND ANTIMICROBIAL ACTIVITIES OF CRAMBE SPP. DURING VEGETATION
}

\author{
Olena Vergun ${ }^{1}$, Dzhamal Rakhmetov ${ }^{1}$, Oksana Shymanska $^{1}$, Oleksandr Bondarchuk ${ }^{1}$, \\ Eva Ivanišová2 ${ }^{2}$ Miroslava Kačaniováa ${ }^{3}$ Olga Grygorieva ${ }^{4 \bowtie}$, Ján Brindza ${ }^{5}$ \\ ${ }^{1}$ Department of Cultural Flora, M. M. Gryshko National Botanical Garden of National Academy of Sciences of Ukraine \\ Timiryazevska 1, 01014 Kyiv, Ukraine \\ 2Department of Technology and Quality of Plant Products, Slovak University of Agriculture in Nitra \\ Trieda Andreja Hlinku 2, 94676 Nitra, Slovakia \\ ${ }^{3}$ Department of Fruit Growing, Viticulture and Enology, Slovak University of Agriculture in Nitra \\ Trieda Andreja Hlinku 2, 94676 Nitra, Slovakia \\ ${ }^{4}$ Department of Fruit Plant Acclimatization, M. M. Gryshko National Botanical Garden of National Academy of Sciences of Ukraine \\ Timiryazevska 1, 01014 Kyiv, Ukraine \\ ${ }^{5}$ Institute of Biological Conservation and Biosafety, Slovak University of Agriculture in Nitra \\ Trieda Andreja Hlinku 2, 94676 Nitra, Slovakia
}

\begin{abstract}
Background. The search for new plant raw material as a potential source of antioxidants is still ongoing. This study aimed to evaluate the antioxidant and antimicrobial capacity of the plant raw material of Crambe spp. during vegetation.

Materials and methods. The free radical scavenging activity and molybdenum reducing power of the extracts were used to determine antioxidant activity. The quantification of polyphenol compounds was conducted with Folin-Ciocalteu reagent. Flavonoids and phenolic acids were also determined. The disc diffusion method was used to determine antimicrobial activity.

Results. It was determined that the free radical scavenging activity, assessed using the DPPH-method, was 4.38-8.20 mg TE/g DW, the molybdenum reducing power of the extracts was 40.07-129.12 mg TE/g DW, total polyphenol content was $20.24-70.88 \mathrm{mg} \mathrm{GAE} / \mathrm{g}$ DW, total flavonoid content was 5.73-29.92 mg QE/g $\mathrm{DW}$, and phenolic acid content was 3.00-10.63 mg CAE/g DW. Antimicrobial activity depended on the stage of growth and the part of the plant used.

Conclusion. Crambe spp. possess the antioxidant and antimicrobial potential to mean that they could be used in pharmaceutical studies and the food industry.
\end{abstract}

Keywords: Crambe spp., polyphenols, antioxidant capacity, antimicrobial activity

\section{INTRODUCTION}

Brassicaceae Burnett is a large family with economically important plants such as Brassica L. (Cömert Önder et al., 2020; Francisco et al., 2016), Camelina Crantz (Zubr, 2010), Crambe L. (Lovatto et al., 2017; Wang et al., 2000) etc. with a rich source of health-improving phytochemicals (Avato and Argentieri, 2015). Members of the Brassicaceae exhibit various biological functions including antimicrobial, antioxidant, antiviral, and anticancer, etc. (Shankar et al., 2019). 
The genus Crambe L. consists of about 40 species in the world (Francisco-Ortega et al., 2002). Plants from this genus are mostly represented by perennial and economically important crops. Among others, the most common species is Crambe hispanica subsp. abyssinica (Hochst. ex R. E. Fr.) Prina wide is used as an oil plant, the seeds of which contain approximately $40 \%$ oil (Silva et al., 2019). In addition, the seed oil of this plant contains erucic acid, which has the potential for use in industry (Li et al., 2012). Bassegio et al. (2016) reviewed the potential application of $C$. abissinica mainly associated with the manufacture of biodiesel. Crambe meal is an important raw material that can contain up to $50 \%$ crude protein and has a digestibility level similar to soybean meal (Samarappuli et al., 2020). Some of the species from this genus are promising medicinal plants (Kalista, 2017). C. mariti$m a$ (sea kale) and C. hispanica subsp. abyssinica are potential salt-tolerant crops (Francois and Kleiman, 1990; de Vos et al., 2010).

A study of the fatty acid composition showed that $\alpha$-linolenic acid in the leaves and oleic acid in the seeds of samples of $C$. tataria Sebeók were the dominant fatty acids (Pushkarova et al., 2016). Previous studies of the makeup of Crambe spp. nutrients determined that 9.76-22.54\% was dry matter, $6.54-33.18 \%$ was the total content of sugars, $139.85-987.02 \mathrm{mg} / 100 \mathrm{~g}$ was ascorbic acid, $0.38-2.41 \mathrm{mg} / 100 \mathrm{~g}$ was $ß$-carotene, $1.28-6.47 \%$ was tannins, $3.12-6.28 \%$ was titratable acidity, etc. during vegetation (Vergun et al., 2019b). Among the photosynthetic pigments, the highest content of carotenoids was found in the leaves of C. koktebelica during fruiting (Vergun et al., 2019a).

Study of the biological activities of Crambe spp. showed that selected species have been investigated. Extracts of $C$. cordifolia plants possessed antioxidant (Bukhari et al., 2013), antimicrobial, and hemolytic activities (Rashid et al., 2018). The study of antioxidant activity in vivo and in vitro samples of C. tataria was higher than the ascorbic acid solution in the same experiment (Pushkarova et al., 2016). Leaf extracts of C. cordifolia and C. koktebelica contained chlorogenic, ferulic, caffeic, p-coumaric, syringic, sinapic, cinnamic, hydroxyphenyl acetic, and quinic acids, as well as neohesperidin, and rutin, etc. (Marchyshyn et al., 2020).

Among the wild and cultured food plants of Brassicaceae, which are used as spices and analysis of which might be interesting, is Armoracia rusticana (P. Gaertn., B. Mey. \& Scherb.). This is a well-known species with a rich content of biologically active compounds (Agneta et al., 2013; Tomsone et al., 2020). It is a well-known plant with biological activities such as antioxidant (Calabrone et al., 2015; Ivanišová et al., 2020), and antimicrobial ones (Park et al., 2013) that is also widely used as a food plant with a pungent smell, intense lachrymatory odor and bitter taste (Rivelli et al., 2017).

This study aimed to evaluate the antioxidant and antimicrobial capacity of the plant raw material of Crambe spp. in the M. M. Gryshko National Botanical Garden of the NAS of Ukraine as a potential source of antioxidants and antimicrobial agents.

\section{MATERIALS AND METHODS}

\section{Plant materials}

In this study we investigated the above-ground part of plants of the Crambe L. species from the experimental collection of M. M. Gryshko National Botanical Garden of the NAS of Ukraine: C. cordifolia Steven (1), C. hispanica subsp. abyssinica (Hochst. ex R. E. Fr.) Prina (2), C. koktebelica (Junge) N. Busch (3), C. maritima L. (4), C. steveniana Rupr. (5) at the stages of budding, flowering, and fruiting during 2018-2019 (Fig. 1). In this study, the above-ground parts of Armoracia rusticana (P. Gaertn., B. Mey. \& Scherb.) were used for antioxidant activity determination and both above-ground and below-ground parts to compare antimicrobial activity. For antimicrobial activity, plant raw material was used at the start of vegetation (phase of the leaf rosette) and the flowering stage.

\section{Chemicals}

All chemicals were analytical grade and were purchased from Reachem (Slovakia) and Sigma Aldrich (USA).

\section{Sample preparation}

$0.2 \mathrm{~g}$ of dried plant raw material was extracted with 20 $\mathrm{ml}$ of $80 \%$ ethanol for 2 hours. After centrifugation at $4000 \mathrm{~g}$ (Rotofix $32 \mathrm{~A}$, Hettich, Germany) for $10 \mathrm{~min}$, the supernatant was used for the next measurements: antioxidant activity, polyphenols, and flavonoids. 


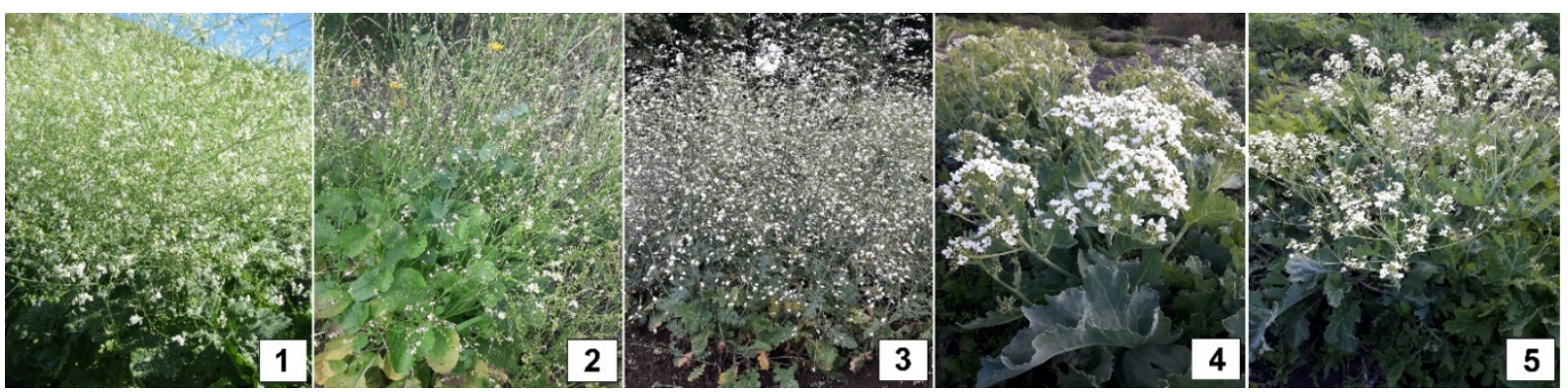

Fig. 1. Investigated plant species of Crambe L. genus at the flowering stage

\section{Free radical scavenging assay (FRSA) by DPPH-method}

The radical scavenging activity of the samples was measured using 2.2-diphenyl-1-picrylhydrazyl (DPPH) (Sánchéz-Moreno et al., 1998). The extracts $(0.5 \mathrm{ml})$ were mixed with $3.6 \mathrm{ml}$ of radical solution $(0.025 \mathrm{~g}$ of DPPH in $100 \mathrm{ml}$ ethanol). The absorbance of the sample extract was determined using a spectrophotometer Jenway (6405UV/Vis, England) at $515 \mathrm{~nm}$. Trolox (6-hydroxy-2,5,7,8-tetramethylchroman-2-carboxylic acid; $10-100 \mathrm{mg} / 1 ; R^{2}=0.988$ ) was used as the standard and the results were expressed in $\mathrm{mg} / \mathrm{g}$ Trolox equivalents.

\section{Molybdenum reducing power of extracts (MRP)}

The reducing power of the extracts was determined using the phosphomolybdenum method of Prieto et al. (1999) with slight modifications. The mixture of the sample $(1 \mathrm{ml})$ of monopotassium phosphate $(2.8$ $\mathrm{ml}, 0.1 \mathrm{M})$, sulfuric acid $(6 \mathrm{ml}, 1 \mathrm{M})$, ammonium heptamolybdate $(0.4 \mathrm{ml}, 0.1 \mathrm{M})$ and distilled water $(0.8$ $\mathrm{ml}$ ) was incubated at $90^{\circ} \mathrm{C}$ for $120 \mathrm{~min}$, then rapidly cooled and detected by monitoring the absorbance at $700 \mathrm{~nm}$ using a spectrophotometer Jenway (6405UV/ Vis, England). Trolox (10-1000 mg/l; $\left.R^{2}=0.998\right)$ was used as the standard and the results were expressed in $\mathrm{mg} / \mathrm{g}$ Trolox equivalents.

\section{Total polyphenol content (TPC)}

The total polyphenol content of the extracts was measured using the method of Singleton and Rossi (1965) using a Folin-Ciocalteu reagent. $0.1 \mathrm{ml}$ of each sample extract was mixed with $0.1 \mathrm{ml}$ of the Folin-Chiocalteu reagent, $1 \mathrm{ml}$ of $20 \%(\mathrm{w} / \mathrm{v})$ sodium carbonate, and $8.8 \mathrm{ml}$ of distilled water. After $30 \mathrm{~min}$ in darkness the absorbance at $700 \mathrm{~nm}$ was measured using a spectrophotometer Jenway (6405UV/Vis, England). Gallic acid $\left(25-250 \mathrm{mg} / \mathrm{l} ; R^{2}=0.996\right)$ was used as the standard and the results were expressed in $\mathrm{mg} / \mathrm{g}$ gallic acid equivalents.

\section{Total flavonoid content (TFC)}

Determination of the total flavonoid content was conducted using the modified method of Shafii et al. (2017). $0.5 \mathrm{ml}$ of the sample extract was mixed with $0.1 \mathrm{ml}$ of $10 \%(\mathrm{w} / \mathrm{v})$ ethanolic solution of aluminum chloride, $0.1 \mathrm{ml}$ of $1 \mathrm{M}$ sodium acetate, and $4.3 \mathrm{ml}$ of distilled water. After 30 min in darkness the absorbance at $415 \mathrm{~nm}$ was measured using a spectrophotometer Jenway (6405UV/Vis, England). Quercetin $\left(0.01-0.5 \mathrm{mg} / \mathrm{l} ; R^{2}=0.997\right)$ was used as the standard and the results were expressed in $\mathrm{mg} / \mathrm{g}$ quercetin equivalents.

\section{Total phenolic acid content (TPAC)}

Determination of the total phenolic acid content of the extracts was carried out using the method of Farmakopea Polska (1999). $0.5 \mathrm{ml}$ of sample extract was mixed with $0.5 \mathrm{ml}$ of $0.5 \mathrm{M}$ hydrochloric acid, $0.5 \mathrm{ml}$ Arnova reagent, $0.5 \mathrm{ml}$ of $1 \mathrm{M}$ sodium hydroxide $(\mathrm{w} / \mathrm{v})$, and $0.5 \mathrm{ml}$ of distilled water. The absorbance at $490 \mathrm{~nm}$ was measured using a spectrophotometer Jenway (6405UV/Vis, England). Caffeic acid (1-200 mg/l, $\left.R^{2}=0.999\right)$ was used as a standard and the results were expressed in $\mathrm{mg} / \mathrm{g}$ caffeic acid equivalents.

\section{Antimicrobial activity}

The ethanolic extracts of the investigated Crambe spp. were subjected to an evaporation procedure under reduced pressure at $40^{\circ} \mathrm{C}$ to remove the ethanol 
(Stuart RE300DB rotary evaporator, Bibby scientific limited, UK, vacuum pump KNF N838.1.2KT.45.18, KNF, Germany). For the next procedure, the dried plant extracts were dissolved in dimethyl sulfoxide (DMSO) (Penta, Czech Republic). Nine strains of microorganisms (Czech Collection of microorganisms) were tested in this study, including three Gram-positive bacteria (Bacillus cereus CCM 869, Clostridium perfingens CCM 4435, Staphylococcus aureus subsp. aureus CCM 4223), three Gram-negative bacteria (Haemophilus influenza CCM 4456, Klebsiella pneumoniae subsp. pneumoniae CCM 4415, Salmonella enterica subsp. enterica CCM 7189), and three yeasts (Candida albicans CCM 8215, C. glabrata CCM 8270, C. tropicalis CCM 8264). The microorganism strains were grown in Mueller-Hinton agar (MHA, Biolife, Italy) in plates at a temperature of $37^{\circ} \mathrm{C}$. The antimicrobial activity of each extract was determined using the disc diffusion method. $100 \mu 1$ of microbial suspension was spread and grown in $1 \mathrm{ml}$ of fresh media until they reached approximately $10^{5}$ cells per $\mathrm{ml}$. After this, $100 \mu \mathrm{l}$ of microbial suspension was spread onto Mueller Hinton agar plates. The extracts were tested using $6 \mathrm{~mm}$ sterilized filter paper discs. The plates were incubated at $37^{\circ} \mathrm{C}$ for 24 hours. Blank discs were impregnated with Ampicillin $(10 \mu \mathrm{g} / \mathrm{disc}$, Oxoid, UK) for Gram-positive bacteria and yeasts, and Gentamicin (10 $\mu \mathrm{g} / \mathrm{disc}$, Oxoid, UK) for Gram-negative bacteria as a positive control. A $1 \%$ solution of DMSO (dimethyl sulfoxide) was used as a negative control. The diameter of the inhibition zone was measured in millimeters. Each antimicrobial assay was performed in triplicate.

\section{Statistical analysis}

The statistically treated data are given in tables as the arithmetical mean values and their standard errors. Data were submitted using ANOVA and the differences between means compared through the Tukey-Kramer test $(\alpha=0.05)$. Correlation analysis was performed using Pearson's criterion.

\section{RESULTS AND DISCUSSION}

Plant raw material, such as leaves, stems, roots, fruits, seeds, and peels, is a valuable source of antioxidants. Natural antioxidants are widely distributed in food and medicinal plants and exhibit sprawling biological effects such as anti-inflammatory, anti-aging, anti-atherosclerosis, and anticancer (Xu et al., 2017). The main group of natural antioxidants is phenolic compounds that are widely distributed in the plant world and involved in oxidative-reduction processes (Babenko et al., 2019). There are numerous methods to determine the antioxidant activity in plant extracts, among which the DPPH scavenging assay (Moharram and Youssef, 2014; Prior et al., 2005) and phosphomolybdenum methods (Alam et al., 2013; Gulcin, 2020) are widely used. Plants from Brassicaceae are characterized by a high antioxidant capacity when raw due to their content of vitamins, carotenoids, and phenolic compounds, etc. (Podsędek, 2007).

\section{Free radical scavenging assay}

Among other methods, the scavenging of the stable radical (DPPH) assay is based on the measurement of the scavenging ability of antioxidants against a radical solution that is also a simple and rapid test (Sánchéz-Moreno, 2002). The antioxidant activity of the investigated extracts, measured using the DPPH method, was from 4.38 (C. koktebelica, budding stage) to 8.20 (C. koktebelica, flowering stage) $\mathrm{mg} \mathrm{TE} / \mathrm{g}$ DW (Fig. 2). For the budding, flowering, and fruiting, we found the FRSA to be $4.38-8.19,4.40-8.20$, and $5.73-8.07 \mathrm{mg}$ TE/g DW, respectively. In this experiment, the $A$. rusticana extracts showed FRSA from 6.56 to $9.11 \mathrm{mg}$ TE/g DW. The highest value of its extracts was obtained at the budding stage among all investigated plants. At the flowering and fruiting stages, the best results were obtained for C. koktebelica and C. hispanica subsp. abyssinica, respectively.

Bukhari et al. (2013) determined the free radical scavenging activity of the methanolic extracts of C. cordifolia as $1106.65 \mu \mathrm{g} / \mathrm{ml}$ as compared to $21.69 \mu \mathrm{g} / \mathrm{ml}$ of ascorbic acid. Dubie et al. (2013) determined the antioxidant activity using DPPH assay in water and methanol extracts of Brassica juncea seed meal as 4.59 and $6.51 \mathrm{mg} / \mathrm{g}$ sinapic acid equivalent. Tomsone and Kruma (2017) detected the DPPH scavenging activity for A. rusticana leaf extracts during vegetation as 37.13$73.38 \mathrm{mM} / 100 \mathrm{~g}$ TE DW. The FRSA of other representatives of Brassicaceae, such as Bunias orientalis, at the stage of flowering was $8.94 \mathrm{mg} \mathrm{TE} / \mathrm{g} \mathrm{DW}$ in the ethanol extracts (Vergun et al., 2018). This parameter 


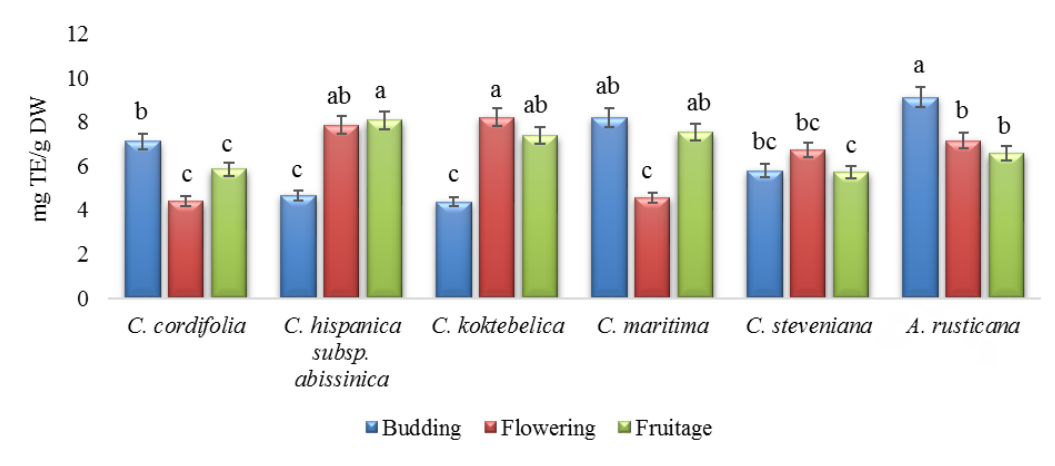

Fig. 2. Free radical scavenging activity using the DPPH-method of ethanol extracts of Crambe spp. during vegetation (different superscripts in each column indicate significant differences in the mean at $P<0.05)$ : TE - Trolox equivalent

for Brassica campestris and Sinapis alba leaf extracts was 8.17 and $7.15 \mathrm{mg} \mathrm{TE} / \mathrm{g} \mathrm{DW}$, respectively (Vergun et al., 2019c).

\section{Molybdenum reducing power of extracts}

Determination of the antioxidant activity using the phosphomolybdenum method along with other assays allows the identification of the antioxidant capacity of plant raw material. The obtained results of antioxidant capacity can be expressed as $\alpha$-tocopherol or Trolox equivalent (Gulcin, 2020). The MRP of the investigated extracts was from 40.07 (C. maritima, budding stage) to 129.13 (C. steveniana, fruitage) $\mathrm{mg} \mathrm{TE} / \mathrm{g}$ DW (Fig. 3). At the budding, flowering, and fruiting stages we determined 40.07-105.06, 62.01-111.19, and 64.34-129.13 $\mathrm{mg} \mathrm{TE} / \mathrm{g}$, respectively. The $A$. rusticana extracts demonstrated an increase in MRP from the budding to the flowering stage and following a decrease in flowering to fruiting. A comparison of the obtained results of all the investigated extracts showed that at the budding stage similar values of MRP occurred for A. rusticana as well as for C. hispanica subsp. abyssinica. At the flowering stage, this parameter was the highest for A. rusticana extracts, and at fruiting, C. steveniana and C. maritima showed higher values than $A$. rusticana. The extracts of $C$. koktebelica and $C$. cordifolia demonstrated similar results.

Bukharietal. (2013) determined antioxidant activity in C. cordifolia extract using the phosphomolybdenum

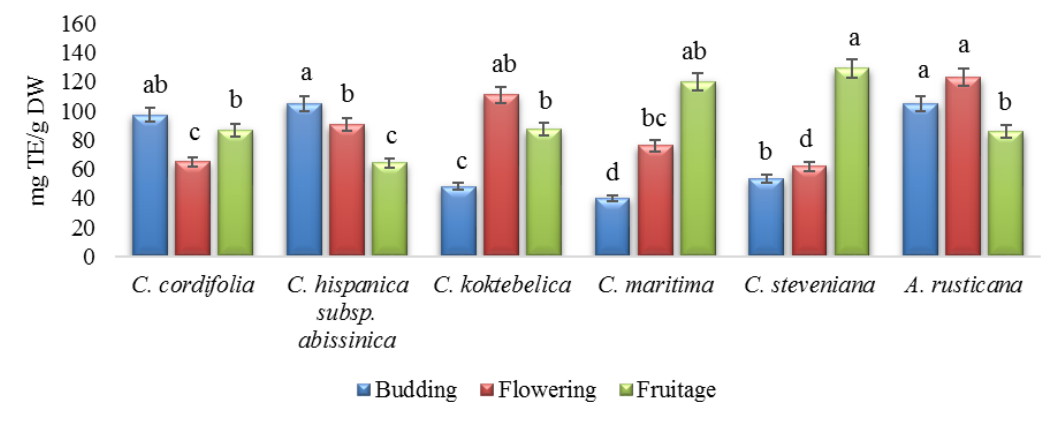

Fig. 3. Molybdenum reducing power of ethanol extracts using the phosphomolybdenum method of Crambe spp. during vegetation (different superscripts in each column indicate significant differences in the mean at $P<0.05$ ): TE Trolox equivalent 
method as $205.73 \mu \mathrm{g} / \mathrm{mg} \alpha$-tocopherol equivalent. The reducing power of $A$. rusticana leaf extracts during vegetation was $2638-9573 \mathrm{mg} / 100 \mathrm{~g}$ of ascorbic acid equivalent DW (Tomsone and Kruma, 2017). The MRP of the ethanol extracts of Bunias orientalis showed the result of $184.59 \mathrm{mg} \mathrm{TE} / \mathrm{g}$ DW (Vergun et al., 2018). In addition, ethanol leaf extracts of Brassica campestris and Sinapis alba showed an MRP of 91.94 and $148.43 \mathrm{mg}$ TE/g DW, respectively (Vergun et al., 2019c).

\section{Total polyphenol content}

Polyphenol compounds are natural phytochemicals that form a major group of semi-water-soluble compounds which are generally found in nature as glycosides (Rasouli et al., 2017). Plants are a valuable source of polyphenols and crops from Brassicaceae are not an exception (Sikora et al., 2008).

The TPC of the investigated extracts of Crambe spp. during vegetation was from 20.24 (C. koktebelica, budding stage) to 70.88 (C. cordifolia, budding stage) mg GAE/g DW (Fig. 4). The TPC in the extracts of $A$. rusticana decreased during vegetation as it did in the extracts of C. cordifolia and C. hispanica subsp. abyssinica but values of this parameter were less. The TPC increased in plants of C. koktebelica and C. maritima during vegetation, where $C$. maritima accumulated these compounds 3 times more during fruiting than at the budding stage.

Rashid et al. (2018) investigated root extracts of C. cordifolia in different solvents and determined the
TPC in methanol extracts to be $210.3 \mu \mathrm{g}$ GAE $/ \mathrm{mg}$, chloroform extracts $122.5 \mu \mathrm{g}$ GAE/mg, ethyl acetate extracts $35.1 \mu \mathrm{g} \mathrm{GAE} / \mathrm{g}$, and hexane extracts $10.7 \mu \mathrm{g}$ GAE/mg DW. Due to less investigation of Crambe spp. polyphenol content and antioxidant activity, these were used to compare with other species from Brassicaceae in this study. Beevi et al. (2010) investigated different extracts of Raphanus sativus leaves and determined the TPC in water and methanol extracts to be 34.16 and $86.16 \mathrm{mg} / \mathrm{g}$ catechin equivalent, respectively. Deveci and Uzun (2011) identified TPC in the leaves of Spinacia oleracea L. at $119.88 \mathrm{mg}$ GAE/100 g FW. Bukhari et al. (2013) found TPC in water extracts of $C$. cordifolia as $10.60 \mu \mathrm{g} / \mathrm{g}$ pyrocatechol equivalent. Dubie et al. (2013) determined the TPC in water and ethanol extracts of Brassica juncea seed meal to be 11.56 and $8.00 \mathrm{mg} / \mathrm{g}$ of sinapic acid equivalent. Goyeneche et al. (2015), in the leaf extracts of $R$. sativus, identified $695.07 \mathrm{mg}$ GAE per $100 \mathrm{~g}$ DW of TPC. Leaf extracts of $A$. rusticana showed TPC of 1235-2705 mg GAE/100 g DW during vegetation (Tomsone and Kruma, 2017). For Bunias orientalis ethanol extracts, this parameter was $52.88 \mathrm{mg}$ GAE/g DW, which was determined at the flowering stage (Comlekcioglu, 2019; Vergun et al., 2018). The TPC was determined for five species of Isatis as being between 8.90 and $19.16 \mathrm{mg} \mathrm{GAE} / \mathrm{g}$. In leaf extracts of Brassica campestris and Sinapis alba TPC was identified as 41.69 and $73.58 \mathrm{mg} \mathrm{GAE} / \mathrm{g} \mathrm{DW}$, respectively (Vergun et al., 2019c).

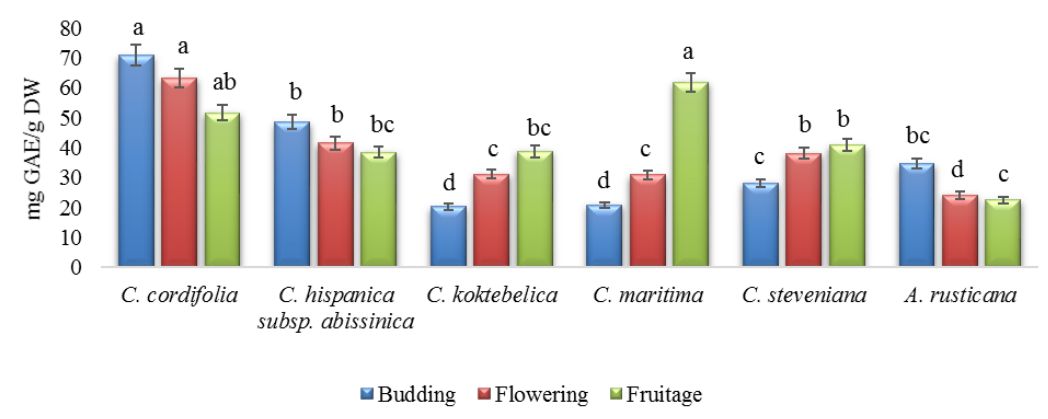

Fig. 4. The total content of polyphenol compounds of ethanol extracts of Crambe spp. during vegetation (different superscripts in each column indicate significant differences in the mean at $P<0.05$ ): GAE - gallic acid equivalent 


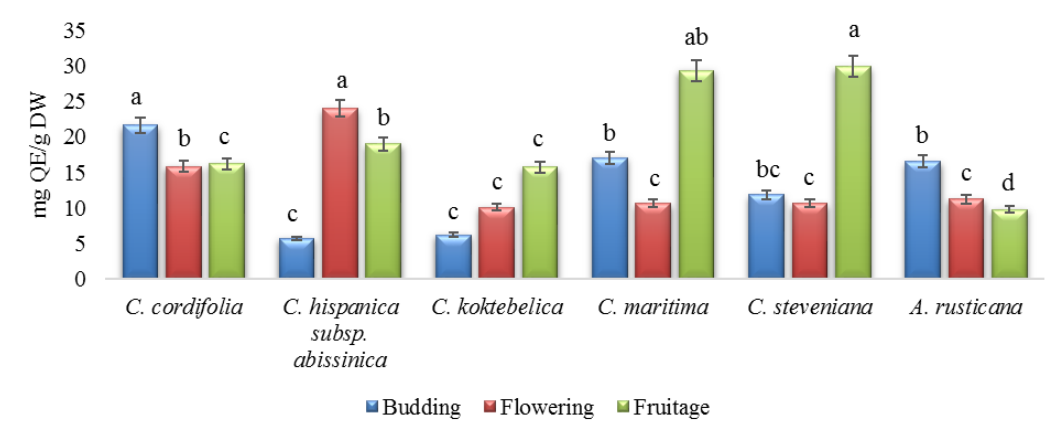

Fig. 5. The total flavonoid content of ethanol extracts of Crambe spp. during vegetation (different superscripts in each column indicate significant differences in the mean at $P<0.05$ ): $\mathrm{QE}$ - quercetin equivalent

\section{Total flavonoid content}

Flavonoids are a large group of polyphenol compounds that are extensively distributed in plant raw material and are very effective antioxidants. They include flavones, flavanols, flavanones, and chalcones represented in the tissues of higher plants (Gulcin, 2020). In our research, the total content of flavonoids (TFC) was from 5.73 (C. hispanica subsp. abissinica, budding stage) to 29.92 (C. steveniana, fruitage) $\mathrm{mg}$ QE/g DW (Fig. 5). Accumulation of flavonoids during vegetation for all investigated species was uneven. Plants of species of C. koktebelica, C. maritima, and C. steveniana contained a maximal level of flavonoids at the fruiting stage before the death of generative shoots. The TFC in A. rusticana plants decreased from budding to fruiting. The maximal content of TFC at the budding stage was identified in extracts of C. cordifolia and A. rusticana, at the flowering stage for $C$. hispanica subsp. abissinica, and at the fruiting stage for C. koktebelica, C. maritima, and C. steveniana.

According to Aguinagalde and Gomez-Campo (1984), in the plant extracts of Crambe spp. kaempferol, quercetin, apigenin, luteolin, etc. were identified. The TFC of the ethanol extracts of C. cordifolia in the report of Bukhari et al. (2013) was $1.43 \mathrm{mg} \mathrm{QE} / \mathrm{mg}$.

Rashid et al. (2018) investigated root extracts of C. cordifolia in different solvents and determined the TFC in methanol extracts to be $75.5 \mu \mathrm{g} \mathrm{QE} / \mathrm{mg}$, hexane extracts $7.09 \mu \mathrm{g} \mathrm{QE} / \mathrm{mg}$, chloroform extracts $48.2 \mu \mathrm{g}$ $\mathrm{QE} / \mathrm{mg}$, and ethyl acetate extracts $18.8 \mu \mathrm{g} \mathrm{QE} / \mathrm{mg}$ of dry weight. In extracts of another species, $A$. rustica$n a$, TFC was found from 2486 to $11697 \mathrm{mg} / 100 \mathrm{~g}$ of catechin equivalent (Tomsone and Kruma, 2017). The comparison with other Brassicaceae species showed the presence of $1042.73 \mathrm{mg} \mathrm{QE} / 100 \mathrm{~g}$ TFC in the leaf extracts of Raphanus sativus (Goyeneche et al., 2015). Bunias orientalis extracts demonstrated TFC at the stage of flowering of $39.91 \mathrm{mg} \mathrm{QE} / \mathrm{g}$ DW (Vergun et al., 2018). Extracts of Isatis spp. contained flavonoids from 115.6 to $430.6 \mu \mathrm{g}$ QE/g (Comlekcioglu, 2019). In the leaf extracts of Brassica campestris and Sinapis alba TFC of 28.37 and $62.91 \mathrm{mg} \mathrm{QE} / \mathrm{g}$, respectively, was found (Vergun et al., 2019c).

\section{Total phenolic acid content}

Phenolic acids are a class of polyphenol compounds that are widely distributed in plants and plant food. The content of these compounds in vegetables and fruits causes a potential protective role against damage by oxidative diseases (Gulcin, 2020). The TPAC of the investigated extracts of Crambe spp. during vegetation was from 3.00 (C. hispanica subsp. abissinica, budding stage) to 10.63 (C. maritima, fruiting) mg CAE/g DW (Fig. 6). The content of TPAC of $A$. rusticana extracts decreased from the budding stage to fruiting, as did TPC and TFC. An increase of TPAC from budding to fruiting was observed in extracts of C. steveniana. The peak of accumulation of TPAC was found at the budding stage for $C$. cordifolia, at the flowering stage for $C$. hispanica subsp. abissinica and C. koktebelica, and at the fruiting stage for C. mariti$m a$ and C. steveniana.

As shown in other reports, the TPAC of Bunias orientalis extracts, for example, was $11.29 \mathrm{mg} \mathrm{CAE} / \mathrm{g}$ 


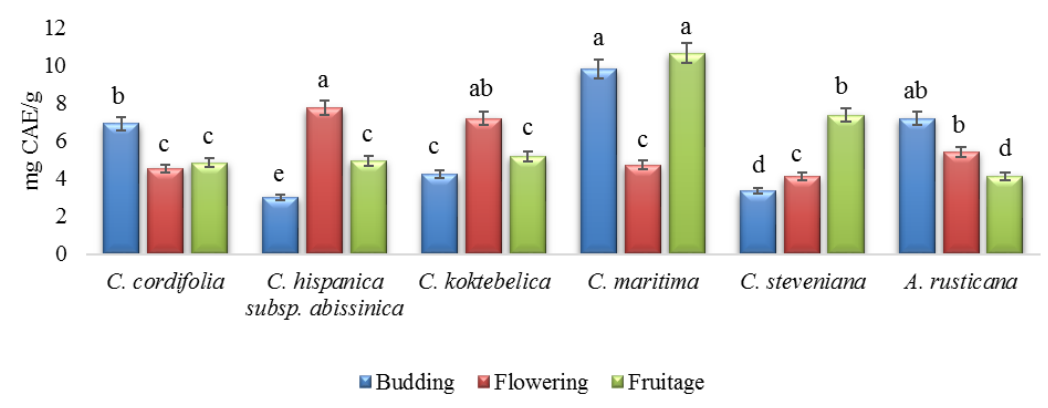

Fig. 6. The total content of phenolic acids of ethanol extracts of Crambe spp. during vegetation (different superscripts in each column indicate significant differences in the mean at $P<0.05$ ): CAE - caffeic acid equivalent

DW at the stage of flowering (Vergun et al., 2018). For the leaf extracts of Brassica campestris and Sinapis alba the TPAC was 4.87 and $9.15 \mathrm{mg} \mathrm{CAE} / \mathrm{g} \mathrm{DW}$, respectively (Vergun et al., 2019c).

Overall, the investigation of polyphenol compound accumulation in all Crambe species was uneven depending on the stage of growth, which could be connected with the biological peculiarities of these plants as perennial (besides $C$. hispanica subsp. abissinica) and their ability to create numerous shoots during the budding and flowering stages. Evidently, this ability can affect the distribution of biologically active compounds, however, it is necessary to investigate this more deeply.

In this study, the results of correlation analysis concerning polyphenols and antioxidant activity are presented. As the parameters of antioxidant activity in Crambe spp. extracts were affected by stages of growth and species, the antioxidant activity also changed. To determine the contribution of different polyphenol compounds to the molybdenum reducing power and free radical scavenging activity, and the relationship between antioxidants markers, correlation analyses were conducted independent of species but related to the phase of growth. The correlation between antioxidant activity and polyphenol compounds in the plant extracts depends on their phenolic composition and the different methods used based on different reaction mechanisms (Tusevski et al., 2014). Very strong correlation was found between TPAC and FRSA $(r=0.907)$ and between TFC and FRSA $(r=0.885)$ at the budding stage and between TPAC and TFC $(r=0.851)$ at the fruiting stage (Table 1). Strong correlation
Table 1. Pearson's correlation coefficients for investigated parameters of Crambe spp.

\begin{tabular}{lcccc}
\hline Parameter & TPC & TFC & TPAC & FRSA \\
\hline Budding & & & & \\
TFC & $0.699^{* *}$ & 1 & & \\
TPAC & $0.423^{*}$ & $0.744^{* *}$ & 1 & \\
FRSA & $0.536^{*}$ & $0.885^{* *}$ & $0.907 * *$ & 1 \\
MRP & $-0.169^{*}$ & $-0.432^{*}$ & $-0.775^{* *}$ & $-0.473^{*}$
\end{tabular}

Flowering

$\begin{array}{lllll}\text { TFC } & 0.439^{*} & 1 & & \\ \text { TPAC } & -0.165^{*} & 0.489^{*} & 1 & \\ \text { FRSA } & -0.231^{*} & 0.209^{*} & 0.777^{* *} & 1 \\ \text { MRP } & -0.515^{*} & -0.685^{* *} & 0.217^{*} & 0.557^{*}\end{array}$

Fruitage

$\begin{array}{lllll}\text { TFC } & 0.383^{*} & 1 & & \\ \text { TPAC } & 0.717 * * & 0.851 * * & 1 & \\ \text { FRSA } & -0.053^{*} & -0.174 * & 0.080^{*} & 1 \\ \text { MRP } & 0.791 * * & -0.249 * & 0.161 * & 0.020^{*}\end{array}$

TPC - total polyphenol content, TFC - total flavonoids content, TPAC - total phenolic acid content, FRSA - free radical scavenging assay, MRP - molybdenum reducing power.

* Correlation is significant at the level of 0.05 .

** Correlation is significant at the level of 0.01 
between TPAC and FRSA $(r=0.777), \mathrm{TFC}$ and TPAC $(r=0.744)$, TPAC and TPC $(r=0.717)$, and TPC and TFC $(r=0.699)$ was found at the budding stage.

Correlation analysis was also performed for each species and showed differences in the accumulation of investigated compounds. So, in extracts of C. cordifolia a very strong correlation was found between TFC and TPAC $(r=0.997)$, FRSA and MRP $(r=0.987)$, TPAC and FRSA $(r=0.902)$, TFC and FRSA $(r=$ $0.871)$, and TPAC and MRP $(r=0.823)$. A strong correlation was determined between TPC and TFC $(r=0.764)$, TPC and TPAC $(r=0.718)$.

A very strong correlation in the $C$. hispanica subsp. abissinica extracts was found between the following parameters: TFC and FRSA $(r=0.947), \mathrm{TFC}$ and TPAC $(r=0.934)$, and TPC and MRP $(r=0.921)$. A strong correlation was determined between TPAC and FRSA $(r=0.772)$.

A very strong relation in the $C$. koktebelica extracts was determined between the following investigated parameters: FRSA and MRP $(r=0.984)$, TPC and TFC $(r=0.978)$, TPAC and MRP $(r=0.943)$, TPAC and FRSA $(r=0.870)$, TPC and FRSA $(r=0.811)$. A strong correlation was detected between TPC and $\operatorname{MRP}(r=0.694)$, and TFC and FRSA $(r=0.673)$.

For $C$. maritima a strong correlation was found between TPC and MRP $(r=0.973)$, TPAC and FRSA $(r=0.954)$, TFC and TPAC $(r=0.841)$, and TPC and TFC $(r=0.834)$. A strong correlation was determined between TFC and MRP $(r=0.686)$, and TFC and FRSA $(r=0.641)$.

A very strong correlation was found between TPAC and MRP $(r=0.997)$, TFC and MRP $(r=0.987)$, and TFC and TPAC $(r=0.972)$ in extracts of $C$. stevenia$n a$. A strong relationship between the investigated parameters was found for TPC and TPAC $(r=0.786)$, TPC and MRP $(r=0.738)$, and TPC and TFC $(r=$ $0.620)$. A significant correlation between the antioxidant activity and polyphenol compounds of Crambe spp. demonstrated that MRP and FRSA depended on the phenolic constituents. These results suggest that relationships between the investigated parameters depend on the species rather than on the stage of growth since in some cases, analyzing concrete species, the correlation between antioxidant activities and different groups of polyphenols was higher than in generalized analysis. In addition, the strong relationship between the investigated parameters depended on the antioxidant activity assay. It is interesting that the interrelationship between all groups of polyphenols and between all polyphenols and FRSA for A. rusticana was very strong $(r=0.954-0.999)$, while a moderate correlation was found between TPAC and MRP $(r=$ 0.439 ). A weak or strong negative correlation between the investigated parameters may suggest that a strong correlation of FRSA and MRP in the Crambe spp. extracts was caused by other compounds rather than groups of polyphenols.

Tomsone and Kruma (2017) reported a strong positive correlation between TPC, TFC, DPPH scavenging activity, and the reducing power of $A$. rusticana extracts. We found a moderate correlation between these parameters at the flowering stage $(r=0.557)$. It should be noted that different methods of antioxidant activity determination can be correlated (Muzykiewicz et al., 2020).

\section{Antimicrobial activity}

The antimicrobial properties of ethanolic extracts of Crambe spp. were determined in above-ground parts and below-ground parts (Tables 2-4) of the plants. One of the most common methods to evaluate the antimicrobial potential of plant extracts is the disc diffusion method (Balouiri et al., 2016). Ethanol extracts of plants from Brassicaceae showed significant antimicrobial activity against selected pathogens (Prasad, 2014). For example, different extracts of Brassica oleracea var. capitata rubra showed inhibition against Bacillus subtilis, Staphylococcus aureus, etc. (Ayshwarya and Sudha Rameshwari, 2015).

At the start of vegetation, plant extracts of the above-ground parts of C. cordifolia and C. koktebelica weren't active against microbial strains. In this period, C. hispanica subsp. abissinica extracts showed an inhibition effect against Staphylococcus aureus subsp. aureus, Bacillus cereus (Table 2). C. steveniana extract inhibited Haemophilus influenzae and Bacillus cereus. In other cases, inhibition of microbial strains wasn't found. Extracts of A. rusticana also weren't effective against microbial strains at the start of vegetation, except Salmonella enterica subsp. enterica.

At the flowering stage, inhibition activity of the above-ground parts of the investigated plant extract was slightly higher. C. cordifolia and C. maritima 
Vergun, O., Rakhmetov, D., Shymanska, O., Bondarchuk, O., Ivanišová, E., Kačaniová, M., Grygorieva, O., Brindza, J. (2021). Assessment of antioxidant and antimicrobial activities of Crambe spp. during vegetation. Acta Sci. Pol. Technol. Aliment., $20(2), 197-211$. http://dx.doi.org/10.17306/J.AFS.2021.0927

Table 2. Antibacterial activity of ethanol extracts of the above-ground parts of Crambe spp. by disc diffusion method, mm

\begin{tabular}{|c|c|c|c|c|c|c|}
\hline Species & Bacillus cereus & $\begin{array}{l}\text { Clostridium } \\
\text { perfingens }\end{array}$ & $\begin{array}{c}\text { Staphylococcus } \\
\text { aureus } \\
\text { subsp. aureus }\end{array}$ & $\begin{array}{l}\text { Haemophilus } \\
\text { influenzae }\end{array}$ & $\begin{array}{c}\text { Klebsiella } \\
\text { pneumo- } \\
\text { niae subsp. } \\
\text { pneumoniae }\end{array}$ & $\begin{array}{c}\text { Salmonella } \\
\text { enterica } \\
\text { subsp. enterica }\end{array}$ \\
\hline \multicolumn{7}{|l|}{ Start of vegetation } \\
\hline C. cordifolia & ND & ND & ND & ND & ND & ND \\
\hline $\begin{array}{l}\text { C. hispanica } \\
\text { subsp. abissinica }\end{array}$ & $2.60 \pm 0.70 \mathrm{a}$ & ND & $1.60 \pm 0.70$ & ND & ND & ND \\
\hline C. koktebelica & ND & ND & ND & ND & ND & ND \\
\hline C. maritima & ND & ND & ND & ND & ND & ND \\
\hline C. steveniana & $1.40 \pm 0.70 \mathrm{~b}$ & ND & ND & $1.30 \pm 0.48$ & ND & ND \\
\hline Armoracia rusticana & ND & ND & ND & ND & ND & $1.20 \pm 0.42$ \\
\hline $\mathrm{AMP} / \mathrm{GEN}$ & $21.17 \pm 1.17 b$ & $21.50 \pm 1.39 b$ & $22.12 \pm 1.18 \mathrm{a}$ & $21.50 \pm 1.87 b$ & $20.67 \pm 1.03 \mathrm{c}$ & $21.67 \pm 1.63 b$ \\
\hline DMSO & ND & ND & ND & ND & ND & ND \\
\hline \multicolumn{7}{|l|}{ Flowering } \\
\hline C. cordifolia & $13.20 \pm 1.99 \mathrm{a}$ & $2.20 \pm 1.03 \mathrm{a}$ & $11.20 \pm 1.55 \mathrm{a}$ & $1.10 \pm 0.32 \mathrm{a}$ & $1.80 \pm 0.63 b$ & $4.10 \pm 1.20 \mathrm{a}$ \\
\hline $\begin{array}{l}\text { C. hispanica } \\
\text { subsp. abissinica }\end{array}$ & $2.10 \pm 0.99 b$ & $1.60 \pm 0.52$ & $7.10 \pm 1.10 \mathrm{~b}$ & ND & ND & $4.70 \pm 0.95 \mathrm{a}$ \\
\hline C. koktebelica & $3.30 \pm 0.48 b$ & $2.90 \pm 0.88 \mathrm{a}$ & $12.70 \pm 1.42 \mathrm{a}$ & ND & $1.20 \pm 0.42$ & $2.70 \pm 1.16 \mathrm{~b}$ \\
\hline C. maritima & $1.08 \pm 1.03 \mathrm{c}$ & $3.00 \pm 1.15 \mathrm{a}$ & $5.10 \pm 0.99 \mathrm{c}$ & $2.20 \pm 1.32 \mathrm{a}$ & $3.80 \pm 0.79 \mathrm{a}$ & $2.00 \pm 0.82 \mathrm{c}$ \\
\hline C. steveniana & $2.60 \pm 1.51 \mathrm{~b}$ & ND & $12.40 \pm 1.90 \mathrm{a}$ & ND & ND & $1.40 \pm 0.52$ \\
\hline Armoracia rusticana & $1.20 \pm 0.42 \mathrm{c}$ & ND & ND & ND & ND & $1.50 \pm 0.47 \mathrm{c}$ \\
\hline AMP/GEN & $20.50 \pm 1.05 b$ & $20.33 \pm 1.51 b$ & $22.47 \pm 1.73 \mathrm{a}$ & $20.00 \pm 1.41 \mathrm{~b}$ & $21.33 \pm 1.37 \mathrm{a}$ & $20.17 \pm 1.17 b$ \\
\hline DMSO & ND & ND & ND & ND & ND & ND \\
\hline
\end{tabular}

ND - not detected inhibition, AMP - Ampicillin, GEN - Gentamicin, DMSO - dimethyl sulfoxide.

Different letters in each column indicate significant differences in the mean at $P<0.05$.

showed activity against all investigated microbial strains (1.10-13.20 and 1.08-5.10 mm, respectively). C. hispanica subsp. abissinica extracts showed inhibition effects $(1.60-7.10 \mathrm{~mm})$ against 7 strains, except Haemophilus influenzae and Klebsiella pneumoniae subsp. pneumoniae. C. koktebelica inhibited the growth of microbial strains on 1.20-12.70 mm, except Haemophilus influenzae. C. steveniana showed an antimicrobial effect from 1.40 to $12.40 \mathrm{~mm}$, except on Clostridium perfingens, Haemophilus influenzae, and Klebsiella pneumoniae subsp. pneumoniae. Extract of
A. rusticana at the flowering stage had low effectiveness against Salmonella enterica subsp. enterica and Bacillus cereus.

In total, ethanol extracts of Crambe spp. underground parts were more effective against microbial strains than above-ground parts (Table 3). Extracts of C. cordifolia showed activity against microbial strains at the start of vegetation and the flowering stage of $2.40-4.00 \mathrm{~mm}$ and $4.40-16.10 \mathrm{~mm}$, with C. hispanica subsp. abissinica at $1.70-3.10 \mathrm{~mm}$ and $4.70-11.10 \mathrm{~mm}$, C. koktebelica at $1.70-7.50 \mathrm{~mm}$ and $4.60-13.10 \mathrm{~mm}$, 
Vergun, O., Rakhmetov, D., Shymanska, O., Bondarchuk, O., Ivanišová, E., Kačaniová, M., Grygorieva, O., Brindza, J. (2021). Assessment of antioxidant and antimicrobial activities of Crambe spp. during vegetation. Acta Sci. Pol. Technol. Aliment., 20(2), $197-211$. http://dx.doi.org/10.17306/J.AFS.2021.0927

Table 3. Antibacterial activity of ethanol extracts of the underground parts of Crambe spp. by disc diffusion method, mm

\begin{tabular}{|c|c|c|c|c|c|c|}
\hline Species & Bacillus cereus & $\begin{array}{l}\text { Clostridium } \\
\text { perfingens }\end{array}$ & $\begin{array}{c}\text { Staphylococcus } \\
\text { aureus } \\
\text { subsp. aureus }\end{array}$ & $\begin{array}{c}\text { Haemophilus } \\
\text { influenzae }\end{array}$ & $\begin{array}{c}\text { Klebsiella } \\
\text { pneumo- } \\
\text { niae subsp. } \\
\text { pneumoniae }\end{array}$ & $\begin{array}{c}\text { Salmonella } \\
\text { enterica } \text { subsp. } \\
\text { enterica }\end{array}$ \\
\hline \multicolumn{7}{|l|}{ Start of vegetation } \\
\hline C. cordifolia & $2.40 \pm 0.52 \mathrm{c}$ & $2.50 \pm 0.71 \mathrm{a}$ & $4.00 \pm 0.82 \mathrm{a}$ & $3.30 \pm 0.67 \mathrm{a}$ & $3.90 \pm 0.99 b$ & $3.60 \pm 0.84 b$ \\
\hline $\begin{array}{l}\text { C. hispanica } \\
\text { subsp. abissinica }\end{array}$ & $3.10 \pm 0.74 b$ & $2.70 \pm 0.67 \mathrm{a}$ & $2.60 \pm 0.84 \mathrm{c}$ & $1.70 \pm 0.67 \mathrm{c}$ & ND & $1.70 \pm 0.67 \mathrm{c}$ \\
\hline C. koktebelica & $1.70 \pm 0.67$ & $2.80 \pm 0.63 \mathrm{a}$ & $4.70 \pm 0.95 \mathrm{a}$ & $3.60 \pm 0.97 a$ & $3.90 \pm 0.99 b$ & $7.50 \pm 0.97 \mathrm{a}$ \\
\hline C. maritima & $4.40 \pm 1.26 \mathrm{a}$ & $1.30 \pm 0.48 b$ & $4.30 \pm 0.82 \mathrm{a}$ & $2.30 \pm 0.48 b$ & $3.30 \pm 0.82 b$ & $7.50 \pm 0.71 \mathrm{a}$ \\
\hline C. steveniana & $1.50 \pm 0.53 \mathrm{c}$ & $2.50 \pm 0.71 \mathrm{a}$ & $3.90 \pm 0.57 b$ & $2.40 \pm 0.52 b$ & $4.60 \pm 1.07 \mathrm{a}$ & $6.80 \pm 0.79 \mathrm{a}$ \\
\hline Armoracia rusticana & $3.00 \pm 0.94 b$ & $2.10 \pm 0.74 \mathrm{a}$ & $4.80 \pm 0.63 \mathrm{a}$ & $2.30 \pm 0.67 b$ & $1.90 \pm 0.74 \mathrm{c}$ & $2.00 \pm 0.82 b$ \\
\hline $\mathrm{AMP} / \mathrm{GEN}$ & $22.17 \pm 1.47 \mathrm{a}$ & $21.67 \pm 1.03 \mathrm{~b}$ & $19.67 \pm 1.03 \mathrm{c}$ & $20.00 \pm 0.89 \mathrm{c}$ & $21.67 \pm 1.03 b$ & $23.33 \pm 1.21 \mathrm{a}$ \\
\hline DMSO & ND & ND & ND & ND & ND & ND \\
\hline \multicolumn{7}{|l|}{ Flowering } \\
\hline C. cordifolia & $4.50 \pm 1.08 \mathrm{c}$ & $4.40 \pm 0.84 \mathrm{~d}$ & $16.10 \pm 0.74 \mathrm{a}$ & $6.90 \pm 1.37 b$ & $4.60 \pm 2.22 \mathrm{c}$ & $5.80 \pm 0.42 \mathrm{c}$ \\
\hline $\begin{array}{l}\text { C. hispanica } \\
\text { subsp. abissinica }\end{array}$ & $6.10 \pm 1.45 b$ & $10.70 \pm 0.82 \mathrm{a}$ & $11.10 \pm 0.99 b$ & $4.70 \pm 0.67 \mathrm{c}$ & ND & $8.70 \pm 0.67 b$ \\
\hline C. koktebelica & $4.60 \pm 0.52 \mathrm{c}$ & $7.50 \pm 1.84 \mathrm{~b}$ & $9.30 \pm 1.06 \mathrm{c}$ & $8.30 \pm 0.67 \mathrm{a}$ & $9.00 \pm 0.47 \mathrm{a}$ & $13.10 \pm 1.45 \mathrm{a}$ \\
\hline C. maritima & $9.30 \pm 0.95 \mathrm{a}$ & $5.90 \pm 0.57 \mathrm{c}$ & $12.30 \pm 1.64 b$ & $5.80 \pm 1.14$ & $7.40 \pm 1.51 \mathrm{~b}$ & $13.80 \pm 1.55 \mathrm{a}$ \\
\hline C. steveniana & $3.30 \pm 0.67 \mathrm{c}$ & $5.60 \pm 0.97 \mathrm{c}$ & $8.20 \pm 0.79 \mathrm{c}$ & $7.50 \pm 0.97 \mathrm{a}$ & $9.10 \pm 0.57 \mathrm{a}$ & $12.60 \pm 1.71 \mathrm{a}$ \\
\hline Armoracia rusticana & $9.70 \pm 0.95 \mathrm{a}$ & $10.10 \pm 1.52 \mathrm{a}$ & $10.70 \pm 1.16 \mathrm{~b}$ & $7.80 \pm 1.40 \mathrm{a}$ & ND & $13.70 \pm 2.10 \mathrm{a}$ \\
\hline $\mathrm{AMP} / \mathrm{GEN}$ & $21.77 \pm 1.10 \mathrm{~b}$ & $21.33 \pm 0.98 b$ & $22.50 \pm 1.05 \mathrm{a}$ & $21.92 \pm 0.86 b$ & $20.52 \pm 0.78 \mathrm{c}$ & $22.15 \pm 1.23 \mathrm{a}$ \\
\hline DMSO & ND & ND & ND & ND & ND & ND \\
\hline
\end{tabular}

ND - not detected inhibition, AMP - Ampicillin, GEN - Gentamicin, DMSO - dimethyl sulfoxide.

Different letters in each column indicate significant differences in the mean at $P<0.05$.

C. maritima at $1.30-7.50 \mathrm{~mm}$ and $5.80-13.80 \mathrm{~mm}$, C. steveniana at $1.50-6.80 \mathrm{~mm}$ and $3.30-12.60 \mathrm{~mm}$, respectively, depending on microbial strains. Extracts of $C$. hispanica subsp. abissinica acted against Klebsiella pneumoniae subsp. pneumoniae in both periods and $A$. rusticana extracts were ineffective against this microbe at the flowering stage. In addition, the highest antimicrobial activity of $A$. rusticana extracts was found against Bacillus cereus.

The best anticandidal activity at the start of vegetation in the investigated extracts was observed in
C. maritima $(6 \mathrm{~mm})$ in the underground parts against Candida albicans (Table 4). A. rusticana extract also showed the best inhibition $(7.10 \mathrm{~mm})$ in this period in the underground part. It should be noted that the above-ground part extracts of $C$. cordifolia, $C$. koktebelica, $C$. steveniana, and $A$. rusticana weren't effective against three Candida strains at the start of vegetation.

At the flowering stage, the highest anticandidal activity was identified for $C$. hispanica subsp. abissinica against Candida albicans $(11.90 \mathrm{~mm})$. A. rusticana 
Vergun, O., Rakhmetov, D., Shymanska, O., Bondarchuk, O., Ivanišová, E., Kačaniová, M., Grygorieva, O., Brindza, J. (2021). Assessment of antioxidant and antimicrobial activities of Crambe spp. during vegetation. Acta Sci. Pol. Technol. Aliment., 20(2), $197-211$. http://dx.doi.org/10.17306/J.AFS.2021.0927

Table 4. Anticandidal activity of ethanol extracts of Crambe spp. by disc diffusion method, mm

\begin{tabular}{|c|c|c|c|c|c|c|}
\hline \multirow[b]{2}{*}{ Species } & \multicolumn{3}{|c|}{ Above-ground part extracts } & \multicolumn{3}{|c|}{ Underground part extracts } \\
\hline & $\begin{array}{l}\text { Candida } \\
\text { albicans }\end{array}$ & $\begin{array}{l}\text { Candida } \\
\text { glabrata }\end{array}$ & $\begin{array}{c}\text { Candida } \\
\text { tropicalis }\end{array}$ & $\begin{array}{l}\text { Candida } \\
\text { albicans }\end{array}$ & $\begin{array}{l}\text { Candida } \\
\text { glabrata }\end{array}$ & $\begin{array}{l}\text { Candida } \\
\text { tropicalis }\end{array}$ \\
\hline \multicolumn{7}{|l|}{ Start of vegetation } \\
\hline C. cordifolia & ND & ND & ND & ND & $1.30 \pm 0.48 \mathrm{~b}$ & $2.40 \pm 0.52 \mathrm{a}$ \\
\hline $\begin{array}{l}\text { C. hispanica } \\
\text { subsp. abissinica }\end{array}$ & $4.70 \pm 0.67 \mathrm{a}$ & $6.60 \pm 0.70 \mathrm{a}$ & $1.40 \pm 0.52$ & $3.60 \pm 1.07 \mathrm{c}$ & $1.80 \pm 0.79 \mathrm{~b}$ & $1.50 \pm 0.53 b$ \\
\hline C. koktebelica & ND & ND & ND & $5.80 \pm 1.55 b$ & $2.50 \pm 0.71 \mathrm{a}$ & $2.90 \pm 0.99 \mathrm{a}$ \\
\hline C. maritima & $3.50 \pm 0.97 \mathrm{~b}$ & $2.40 \pm 0.84 \mathrm{~b}$ & ND & $6.00 \pm 0.82 \mathrm{a}$ & $3.30 \pm 0.48 \mathrm{a}$ & $2.60 \pm 0.52 \mathrm{a}$ \\
\hline C. steveniana & ND & ND & ND & $5.20 \pm 0.79 b$ & $2.50 \pm 0.53 \mathrm{a}$ & $1.90 \pm 0.88 b$ \\
\hline Armoracia rusticana & ND & ND & ND & $7.10 \pm 1.29 \mathrm{a}$ & $2.80 \pm 0.79 \mathrm{a}$ & $1.90 \pm 1.10 \mathrm{~b}$ \\
\hline AMP & $21.77 \pm 2.25 b$ & $21.50 \pm 1.05 b$ & $22.15 \pm 1.19 \mathrm{a}$ & $21.50 \pm 1.05 b$ & $19.67 \pm 0.82 \mathrm{c}$ & $21.00 \pm 1.41 b$ \\
\hline DMSO & ND & ND & ND & ND & ND & ND \\
\hline \multicolumn{7}{|l|}{ Flowering } \\
\hline C. cordifolia & $8.30 \pm 0.67 \mathrm{a}$ & $8.70 \pm 1.16 \mathrm{a}$ & $4.60 \pm 1.17 \mathrm{a}$ & $1.80 \pm 0.79 \mathrm{c}$ & $2.90 \pm 0.57 \mathrm{~d}$ & $4.20 \pm 0.42 \mathrm{c}$ \\
\hline $\begin{array}{l}\text { C. hispanica } \\
\text { subsp. abissinica }\end{array}$ & $7.90 \pm 0.88 \mathrm{a}$ & $3.70 \pm 0.82 b$ & $2.10 \pm 1.37 \mathrm{~b}$ & $11.90 \pm 1.60 \mathrm{a}$ & $5.20 \pm 0.79 \mathrm{c}$ & $8.30 \pm 0.82 b$ \\
\hline C. koktebelica & $6.90 \pm 1.20 \mathrm{~b}$ & $2.10 \pm 0.57 \mathrm{c}$ & ND & $8.50 \pm 0.53 b$ & $5.60 \pm 0.70 \mathrm{c}$ & $7.30 \pm 1.06 \mathrm{~b}$ \\
\hline C. maritima & $7.70 \pm 0.95 \mathrm{a}$ & $7.40 \pm 0.97 \mathrm{a}$ & $2.70 \pm 1.16 \mathrm{~b}$ & $10.50 \pm 2.68 \mathrm{a}$ & $7.30 \pm 0.95 b$ & $5.00 \pm 0.67 \mathrm{c}$ \\
\hline C. steveniana & $8.30 \pm 0.67 \mathrm{a}$ & $2.20 \pm 0.79 \mathrm{c}$ & ND & $7.40 \pm 0.97 b$ & $6.30 \pm 0.95 b$ & $4.90 \pm 0.74 \mathrm{c}$ \\
\hline Armoracia rusticana & ND & ND & ND & $12.10 \pm 2.28 \mathrm{a}$ & $9.10 \pm 0.99 \mathrm{a}$ & $11.80 \pm 1.69 \mathrm{a}$ \\
\hline AMP & $21.83 \pm 1.60 \mathrm{a}$ & $21.17 \pm 1.17 \mathrm{a}$ & $20.17 \pm 0.75 b$ & $21.33 \pm 0.88 \mathrm{a}$ & $20.05 \pm 0.81 \mathrm{~b}$ & $21.12 \pm 1.17 \mathrm{a}$ \\
\hline DMSO & ND & ND & ND & ND & ND & ND \\
\hline
\end{tabular}

$\mathrm{BC}$ - Bacillus cereus, CA - Candida albicans, CG - Candida glabrata, CT - Candida tropicalis, CP - Clostridium perfingens, $\mathrm{ND}$ - not detected inhibition.

Different letters in each column indicate significant differences in the mean at $P<0.05$.

extract showed the best result of inhibition among all the investigated extracts $(12.10 \mathrm{~mm})$.

\section{CONCLUSIONS}

This report demonstrated the potent antioxidant and antimicrobial capacity of ethanol extracts of five species of Crambe during vegetation. However, the accumulation of polyphenol compounds in the aboveground parts of the investigated plants was uneven and depended on the stage of growth and species. The highest level of TCP was found for C. cordifolia at the budding stage, TFC for C. steveniana, and TPAC for C. maritima during fruiting. The maximal values of the FRSA and MRP of extracts were found for C. koktebelica at the flowering stage and C. steveniana at the fruiting stage, respectively. Among the five plant species, C. koktebelica, C. maritima, and C. steveniana accumulated higher TFC during fruiting. The study of antimicrobial activity of the ethanol extracts in the underground parts showed minimal inhibition in extracts of C. maritima against Clostridium perfingens and 
maximal inhibition against Salmonella enterica subsp. enterica. It can be concluded that the antimicrobial effectiveness of the investigated extracts appeared in the underground parts more than the above-ground ones. The obtained data on Crambe spp. is useful for food, pharmacological, and deep biochemical investigations.

\section{REFERENCES}

Agneta, R., Möllers, Ch., Rivelli, A. R. (2013). Horseradish (Armoracia rusticana), a neglected medical and condiment species with a relevant glucosinolate profile: a review. Genet. Res. Crop. Evol., 60, 1923-1943. https:// doi.org/10.1007/s10722-013-0010-4

Aguinagalde, I., Gomez-Campo, C. (1984). The phylogenetic significance of flavonoids in Crambe L. (Cruciferae). J. Linn. Soc., Bot., 89, 277-288.

Alam, M. N., Bristi, N. J., Rafiquzzaman, M. (2013). Review on in vivo and in vitro methods evaluation of antioxidant activity. Saudi Pharm. J., 21, 143-152. http:// dx.doi.org/10.1016/j.jsps.2012.05.002

Avato, P., Argentieri, M. P. (2015). Brassicaceae: a rich source of health improving phytochemicals. Phytochem. Rev., 14, 1019-33. https://doi.org/10.1007/s11101-0159414-4

Ayshwarya, M., Sudha Ramashwari, K. (2015). Antimicrobial activity of the plant extracts of Brassica oleracea var. capitata rubra. JIARM, 3(10), 149-156.

Babenko, L. M., Smirnov, O. E., Romanenko, K. O., Trunova, O. K., Kosakivska, I. V. (2019). Phenolic compounds in plants: biogenesis and functions. Ukr. Biochem. J., 91(3), 5-18. https://doi.org/10.15407/ubj91.03.005

Balouiri, M., Sadiki, M., Ibnsouda, S. K. (2016). Methods for in vitro evaluating antimicrobial activity: A review. J. Pharm. Anal., 6, 71-79. https://dx.doi.org/10.1016/j. jpha.2015.11.005

Bassegio, D., Zanotto, M. D., Ferreira Santos, R., Werncke, I., Pereira Dias, P., Olivo, M. (2016). Oilseed crop crambe as a source of renewable energy in Brazil. Renew. Sust. Energ. Rev., 66, 311-321. https://dx.doi. org/10.1016/j.rser.2016.08.010

Beevi, S. S., Narasu, M. L., Gowda, B. B. (2010). Polyphenolics profile, antioxidant and radical scavenging activity of leaves and stem of Raphanus sativus L. Plant Foods Hum. Nutr., 65, 8-17. https://doi.org/10.1007/ s11130-009-0148-6

Bukhari, S. M., Simic, N., Siddiqui, H. L., Ahmad, V. U. (2013). Determination of antioxidant activity of Crambe cordifolia. World Appl. Sci. J., 22, 11, 1561-1565.
Calabrone, L., Larocca, M., Marzocco, S., Martelli, G., Rossano, R. (2015). Total phenols and and flavonoids content, antioxidant capacity and lipase inhibition of root and leaf horseradish (Armoracia rusticana) extracts. Food Nutr. Sci., 6, 64-74. https://dx.doi.org/10.4236/ fns.2015.61008

Cömert Önder, F., Doğrular, N., Gunduzalp, E., Barlak, S., Ay, M. (2020). A comparative study of three Brassicaceae vegetables grown in Canakkale: determination of total phenolic content and antioxidant activity of pulp and juice samples of radish (Raphanus sativus L.), cabbage (Brassica oleracea L. var capitata L.) and cauliflower (Brassica oleracea L.). J. Grad. School Nat. Appl. Sci., 6(1), 30-38. https://doi.org/10.28979/comufbed.633456

Comlekcioglu, N. (2019). Bioactive compounds and antioxidant activity in leaves of endemic and native Isatis spp. in Turkey. Braz. Arch. Biol. Technol., 62, e19180330. http://dx.doi.org/10.1590/1678-4324-2019180330

Deveci, M., Uzun, E. (2011). Determination of phenolic compounds and chlorophyll content of spinach (Spinacia oleracea L.) at different growth stages. Asian J. Chem., 23(8), 3739-3743.

Dubie, J., Stancik, A., Morra, M., Nindo, C. (2013). Antioxidant extraction from mustard (Brassica juncea) seed meal using high-intensity ultrasound. J. Food Sci., 78(4), 542-548. https://doi.org/10.1111/1750-3841.12085

Farmakopea Polska (1999). The Polish Pharmaceutical Society. Retrieved January 1, 2017, from: http://www.ptfarm.pl/?pid=1\&language $=$ en

Francisco, M., Tortosa, M., Martínez-Ballesta, C. M., Velasco, P., García-Viguera, C., Moreno, D. A. (2016). Nutritional and phytochemical value of Brassica crops from the agri-food perspective. Ann. Appl. Biol., 170, 273-285. https://doi.org/10.1111/aab.12318

Francisco-Ortega, J., Fuertes-Aguilar, J., Kim, S.-Ch., Santos-Guerra, A., Crawford, D. J., Jansen, R. K. (2002). Phylogeny of the Macaronesian endemic Crambe section Dendrocrambe (Brassicaceae) based on internal transcribed spacer sequences of nuclear ribosomal RNA. Am. J. Bot., 89(12), 1984-1990. https://doi.org/10.3732/ ajb.89.12.1984

Francois, L. E., Kleiman, R. (1990). Salinity effect on vegetative growth, seed yield, and fatty acid composition of Crambe. Agron. J., 82(6), 1110-1114. https://doi. org/10.2134/agronj1990.00021962008200060017x

Goyeneche, R., Roura, S., Ponce, A., Vega-Galvez, A., Quispe-Fuentes, I., Uribe, E., Di Scala, K. (2015). Chemical characterization and antioxidant capacity of red radish (Raphanus sativus L.) leaves and roots. J. 
Funct. Foods, 16, 256-264. http://dx.doi.org/10.1016/j. jff.2015.04.049

Gulcin, I. (2020). Antioxidants and antioxidant methods: an updated overview. Arch. Toxicol., 94, 651-715. https:// doi.org/10.1007/s00204-020-02689-3

Ivanišová, E., Vasková, D., Zagula, G., Grynshpan, D., Savitskaya, T. A., Kačaniová, M. (2020). Phytochemical profile and biological activity of selected kind of medicinal herbs. Potr. Slov. J. Food Sci., 14, 573-579. https:// doi.org/10.5219/1370

Kalista, M. (2017). Underutilized medicinal species of Crambe L. from the flora of Ukraine. Agrobiodiv. Impr. Nut. Health Life Qual., 1, 216-220. http://dx.doi. org/10.15414/agrobiodiversity.2017.2585-8246.216-220

Li, X., van Loo, E. N., Gruber, J., Fan, J., Guan, R., Frenzen, M., Stymne, S., Zhu, L.-H. (2012). Development of ultra-high erucic acid oil in the industrial oil crop Crambe abissinica. Plant Biotechnol. J., 862-870. https://doi. org/10.1111/j.1467-7652.2012.00709.x

Lovatto, N. M., Goulart, F. R., Loureiro, B. B., Speroni, C. S., Bender, A. B. B., Giacomini, S. J., ..., Silva, L. P. (2017). Crambe (Crambe abissinica) and sunflower (Helianthus annuus) protein concentrates: production methods and nutritional properties for use in fish feed. An. Acad. Bras. Ciênc., 89, 2495-2504. https://dx.doi. org/10.1590/0001-3765201720140630

Marchyshyn, S., Skrynchuk, O., Buidniak, L., Mosula, L. (2020). Investigation of phenolic compounds of the leaves of Crambe cordifolia Steven and Crambe koktebelica (Junge) N. J. Pharm. Innov., 9(1), 14-17.

Moharram, H. A., Youssef, M. M. (2014). Methods for determining the antioxidant activity: a review. AJFS, 11(1), 31-42. https://doi.org/10.12816/0025348

Muzykiewicz, A., Zielonka-Brzezicka, J., Siemak, J. (2020). Antioxidant activity and polyphenol content in extracts from various parts of fresh and frozen mangosteen. Acta Sci. Pol. Technol. Aliment., 19(3), 261-270. https://doi. org/10.17306/J.AFS.2020.0788

Park, H.-W., Choi, K.-D., Shin, I.-Sh. (2013). Antimicrobial activity of isothiocyanates (ITCs) extracted from horseradish (Armoracia rusticana) root against oral microorganisms. Biocontrol Sci., 18(3), 163-168. https://doi. org/10.4265/bio. 18.163

Podsędek, A. (2007). Natural antioxidants and antioxidant capacity of Brassica vegetables: A review. LWT - Food Sci. Technol., 40(1), 1-11. https://doi.org/10.1016/j. lwt.2005.07.023

Prasad, M. P. (2014). Antimicrobial potential of Brassicaceae family against clinical isolates. Int. J. Pure Appl. Biosci., 2(2), 158-162.
Prieto, P., Pineda, M., Aguilar, M. (1999). Spectrophotometric quantitation of antioxidant capacity through the formation of a phosphomolybdenum complex: specific application to the determination of vitamin $\mathrm{E}$. Anal. Biochem., 269, 337-241. https://doi.org/10.1006/ abio. 1999.4019

Prior, R. L., Wu, X., Schaich, K. (2005). Standartized methods for the determination of antioxidant capacity and phenolics in foods and dietary supplements. J. Agricult. Food Chem., 53, 4290-4302. https://doi.org/10.1021/ jf0502698

Pushkarova, O., Kalista, M., Kharhota, M., Rakhmetov, D., Kuchuk, M. (2016). Crambe tataria Sebeók seeds and plants grown in vitro and in vivo fatty acid composition comparison. Potrav. Slov. J. Food Sci., 10(1), 494-498. https://doi.org/10.5219/646

Rashid, M. A., Akhtar, M. N., Ashraf, A., Nazir, S., Ijaz, A., Omar, N. A., ..., Tareen, R. B. (2018). Chemical composition and antioxidant, antimicrobial and haemolitic activities of Crambe cordifolia roots. Farmacia, 66(1), 165-171.

Rasouli, H., Farzaei, M. H., Khodarahmi, R. (2017). Polyphenols and their benefits: A review. Int. J. Food Prop., 20(2), 1700-1741. https://doi.org/10.1080/10942912.20 17.1354017

Rivelli, A. R., Caruso, M. C., Maria, S., Galgano, F. (2017). Vitamin $\mathrm{C}$ content in leaves and roots of horseradish ( $\mathrm{Ar}$ moracia rusticana): seasonal variation in fresh tissues and retention as affected by storage conditions. Emir. J. Food Agric., 29(10), 799-806. https://doi.org/10.9755/ ejfa.2017.v29.i10.1294

Samarappuli, D., Zanetti, F., Berzuini, S., Berti, M. T. (2020). Crambe (Crambe abissinica Hochst): a non-food oilseed crop with great potential: a review. Agronomy, 10, 1380. https://doi.org/10.3390/agronomy10091380

Sánchéz-Moreno, C., Larrauri, A., Saura-Calixto, F. (1998). A procedure to measure the antioxidant efficiency of polyphenols. J. Sci. Food Agric., 76(2), 270-276. https://doi.org/10.1002/(SICI)1097-0010(199802) 76:2\%3C270::AID-JSFA945\%3E3.0.CO;2-9

Sánchéz-Moreno, C. (2002). Review: methods used to evaluate the free radical scavenging activity in foods and biological systems. Food Sci. Technol. Int., 8(3), 121-137.

Shafii, Z. A., Basri, M., Malek, E. A., Ismail, M. (2017). Phytochemical and antioxidant properties of Manilkara zapota (L.) P roen fruit extracts and its formulations for cosmeceutical application. Asian J. Plant Sci., 7(3), $29-41$.

Shankar, S., Segaran, G., Sundar, R. D. V., Settu, S., Sathiavelu, M. (2019). Brassicaceae - a classical review on 
its pharmacological activities. Int. J. Pharm. Sci. Rev. Res., 55(1), 107-113.

Sikora, E., Cieślik, E., Topolska, K. (2008). The sources of natural antioxidants. Acta Sci. Pol., Technol. Aliment., $7(1), 5-17$.

Silva da, M. F., Araújo, E. F., Silva da, L. J., Amaro, H. T. R., Santos Dias dos, L. A., Santos Dias dos, D. C. F. (2019). Tolerance of crambe (Crambe abyssinica Hochst) to salinity and water stress during seed germination and initial seedling growth. Sci. Agrotec., 43, e025418. http:// dx.doi.org/10.1590/1413-7054201943025418

Singleton, V. L., Rossi, J. A. (1965). Colorimetry of total phenolics with phosphomolybdic-phosphotungstic acid reagent. Am. J. Enol. Vitic., 16(3), 144-158.

Tomsone, L., Kruma, Z. (2017). Influence of gravest time on the phenolic content of horseradish leaves. Foodbalt, 45-50. https://doi.org/10.22616/foodbalt.2017.019

Tomsone, L., Galoburda, R., Kruma, Z., Dirrieu, K., Cinkmanis, I. (2020). Microencapsulation of horseradish (Armoracia rusticana L.). Foods, 9, 1332. https://doi. org/10.3390/foods9091332

Tusevski, O., Kostovska, A., Iloska, A., Trajkovska, L., Gazdovska Simic, S. (2014). Phenolic production and antioxidant properties of some Macedonian medicinal plants. Cent. Eur. J. Biol., 9(9), 888-990. https://doi. org/10.2478/s11535-014-0322-1

Vergun, O., Kačaniová, M., Rakhmetov, D., Shymanska, O., Bondarchuk, O., Brindza, J., Ivanišová, E. (2018). Antioxidant and antimicrobial activity of Bunias orientalis L. and Scorzonera hispanica L. ethanol extracts. Agrobiodiv. Impr. Nut. Health Life Qual., 2, 29-38. https:// doi.org/10.15414/agrobiodiversity.2018.2585-8246. 029-038
Vergun, O., Rakhmetov, D., Shymanska, O., Fishchenko, V. (2019a). Estimation of photosynthetic pigments in the leaves of Crambe spp. during vegetation. Agrobiodiv. Impr. Nut. Health Life Qual., 3, 373-381. https://doi.org/ 10.15414/agrobiodiversity.2019.2585-8246.373-381

Vergun, O., Shymanska, O., Rakhmetov, D., Fishchenko, V., Bondarchuk, O., Rakhmetova, S. (2019b). Accumulation of nutrients in the raw of Crambe species. Agrobiodiv. Impr. Nut. Health Life Qual., 3, 323-332. https:// doi.org/10.15414/agrobiodiversity.2019.2585-8246. 323-332

Vergun, O. M., Rakhmetov, D. B., Shymanska, O. V., Fishchenko, V. V., Ivanišová, E., Brindza, J. (2019c). Leaves extracts of selected crops as potential source of antioxidants. Introdukt. Rosl., [Plant Introduction], 84(1), 82-88. https://doi.org/10.5281/zenodo.3566626

Vos, A. C. de, Broekman, R., Groot, M. P., Rozema, J. (2010). Ecophysiological response of Crambe mariti$m a$ to airborne and soil-borne salinity. Ann. Bot., 105, 925-937. https://doi.org/10.1093/aob/mcq072

Wang, Y. P., Tang, J. S., Chu, C. Q., Tian, J. (2000). A preliminary study on the introduction and cultivation of Crambe abyssinica in China, an oil plant for industrial uses. Ind. Crop. Prod., 12, 47-52.

Xu, D.-P., Li, Y., Meng, X., Zhou, T., Zhou, Y., Zheng, J., ..., Li, H.-B. (2017). Natural antioxidants in food and medicinal plants: extraction, assessment, and resources. Int. J. Mol. Sci., 18, 96. https://doi.org/10.3390/ ijms 18010096

Zubr, J. (2010). Carbohydrates, vitamins and minerals of Camellina sativa seed. Nutr. Food Sci., 40(5), 523-531. 
